\title{
Subject Matter Competency Perceptions of Teacher Educators in Education Faculties of Turkey
}

\author{
Fatma Gözalan Çiçek ${ }^{1} \&$ Mehmet Taşpınar ${ }^{2}$ \\ ${ }^{1}$ Department of Curricula and Teaching Materials, DG for VET, Ministry of National Education, Ankara, Turkey \\ ${ }^{2}$ Department of Educational Sciences, Faculty of Education, Gazi University, Ankara, Turkey \\ Correspondence: Fatma Gözalan Çiçek, Department of Curricula and Teaching Materials, DG for VET, Ministry \\ of National Education, Ankara, Turkey. E-mail: fatmagozalan@hotmail.com
}

Received: September 13, 2020

Accepted: October 21, 2020

Online Published: January 29, 2021

doi:10.5539/ies.v14n2p76

URL: https://doi.org/10.5539/ies.v14n2p76

\begin{abstract}
The purpose of the current study is to determine teacher educators' level of general subject matter competency perception and to investigate whether this level varies depending on different variables. In the collection of the data of the study employing the survey model, a single dimension and 106-item "scale of teacher educators' general subject matter competency perceptions" was used. The scale was prepared in the online environment and sent to 8200 faculty members working in education faculties all over Turkey by e-mail. A total of 789 teacher educators responded to the scale. It was found that the teacher educators generally consider themselves highly competent in terms of general subject matter competences. The area with the lowest competence perception level was found to be foreign language. The teacher educators' general subject matter competence perceptions were found to be not varying significantly depending on their gender, type of the university where they are working (state/foundation), academic title, discipline (educational sciences/subject area education) and teaching experience. In light of these findings, it can be argued that these competences should be considered in the recruitment of teacher educators in education faculties.
\end{abstract}

Keywords: teacher educators, teacher educators' general subject matter competences, competence, teacher training, education faculty

\section{Introduction}

\subsection{Problem Statement}

As a natural result of the rapid advancement of science and technology, global changes affect all areas of human life. Therefore, human resources should be used efficiently. In order to respond to the demands of global change, original education programs and qualified education processes are needed (Jusuf, 2005). Qualified education processes require qualified teachers and qualified teachers educators are needed for qualified teachers (Goodwin et al., 2014). In this connection, it is necessary to define who the teacher educators are.

Teacher educators are people who train teachers. Such a definition is a very general statement in terms of determining competences for teacher educators. Thus, this general statement should be more specified (Fisher et al., 2008) because teacher educators do not have a uni-dimensional identity. In this regard, teacher educators can be classified as follows (Fisher et al., 2008):

- People who provide instructional services and conduct research in higher education.

- People who provide teaching at school and monitor pre-service teachers' school experience.

- People who plan advanced professional activities for school administrators or teachers and conduct instructional activities.

- People who design, implement and evaluate professional works for teachers in other institutions (e.g. staff in the Ministry of Education, professional association managers).

The standards and competency requirements for teacher educators are generally determined by the central authorities of countries (e.g. national advisory committee, accreditation commissions, ministry) and university and school staff working with them (Caena, 2012). Those who have the competences that teacher educators should have can take part in the development of teacher training programs (Association of Teacher Educators, 2003; 


\section{Koster \& Dengerink, 2008).}

The countries that come to the fore in the studies carried out abroad regarding the general subject matter competences of teacher educators are the United States and the Netherlands. Some EU countries have developed standards regarding the competences of teacher educators, while others are still in the process of developing. One of the countries having teacher educator standards is the United States. As stated by Fisher et al. (2008), "Teacher Educator Standards" prepared by the Association of Teacher Educators (ATE), which includes members from many states in the United States at the Winter Conference Standards Clinic, consist of nine items: 1-Teaching, 2-Cultural Competence, 3-Academic Work, 4-Professional Development, 5-Curriculum Development, 6-Cooperation, 7-Community Support, 8-Teacher Education Profession, 9-Vision-related standards. In the Netherlands, another country that comes to the fore in this regard, a professional standard model was prepared by "the Dutch Teacher Educators Association" (Vereniging van Lerarenopleiders Nederland-VELON). In the model, the main basic principles and competence areas of the profession are kept separate. While the basic principles are at the centre of the model, there are competences grouped in four main competence areas around the principles. These are:

- Pedagogy of education.

- Professional learning.

- Organization and management.

- Developmental dimensions.

As can be seen, competences required from teacher educators vary from country to country. As stated in the study by Melief et al. (2012), the competences prepared for teacher educators in the Netherlands are used for the entry of teacher educators into the profession. In addition, the MOFET Institute, established as an inter-university board in Israel for the development and research of teacher education programs, uses ATE standards in the USA (Mofet Institute, 2016).

Another remarkable dimension about teacher educators abroad is the research carried out to determine the identity development, professional development needs of teacher educators and the problems related to the instructional and educational policies they face. In this research, it has been revealed that teacher educators regard research as important for them, and that the majority (83\%) could do their academic research. The difficulties encountered by teacher educators such as difficulty in attaining researcher identity, indecision regarding self-academic identity, and failure to establish academic reliability has also been investigated. It has been revealed that they need to develop themselves in terms of acquiring new technology related skills and being a role model for pre-service teachers. At the same time, it has been emphasized that they need to be able to motivate pre-service teachers and provide them with creative learning environments (Czerniawski et al., 2015; Izadinia, 2014; Martinez, 2008; Tillema \& Kremer-Hayon, 2005; Williams, 2014).

In this connection, some attempts have been made by the Ministry of National Education (2008) in Turkey to determine teacher competences. However, there is no research in Turkey directed to the determination of teacher educators' perceptions of their general subject matter competences. In higher education; on the other hand, there is some research conducted on special content competences (educational technology, scientific research etc.) of teacher educators in education faculties. In this research, teacher educators' perceptions of competences were found to be high in general (Andrew, 2007; Drent \& Meelissen, 2008, Holme et al., 2016; Murat et al., 2006; Krumsvik, 2014; Özüdoğru \& Çakır, 2014; Timmerman, 2009; Tümkaya \& Hurioğlu, 2013; Uysal, 2013).

As there is no study investigating teacher educators' perceptions of competences in Turkey, based on studies abroad, it can be said that the most important factor in teacher training is the teaching staff. In this connection, the current study is believed to make some important contributions to the determination of general subject matter competences of teacher educators in Turkey and to the quality training of teacher educators.

\subsection{Purpose of the Study}

The purpose of the current study is to determine the general subject matter competences of teacher educators in Turkey and their level of perceptions of the extent to which they have these competences.

To this end, answers to the following questions were sought:

- What are the general subject matter competences of teacher educators according to opinions of experts on teacher training?

- What are the opinions of teacher educators working in institutions where teacher are trained about "the general subject matter competences of teacher educators" determined on the basis of expert opinions? 
- What is the extent to which the teacher educators perceive themselves as competent in "the general subject matter competences of teacher educators" determined on the basis of expert opinions?

- Do the teacher educators' competence perceptions vary significantly depending on

a) The discipline in which they are working,

b) Type of the faculty graduated,

c) Type of the university where they are working,

d) Number of years spent in the profession,

e) Academic title,

f) Their state of whether having experienced the profession of teaching as a teacher?

\section{Method}

\subsection{Research Model}

The current study was designed on the basis of the survey model. The survey model is a research model aiming to reveal a state as it is (Karasar, 2007) and is widely used in social sciences (Tanrı̈ğgen, 2009). Thus, in the current study it was used to describe the current state of the teacher educators' general subject matter competences.

\subsection{Population and Sample}

The population of the study consists of all the teacher educators working in the education faculties of the universities in Turkey. Swennen et al. (2010) investigated many studies and concluded that teacher educators are in fact defined as instructors in higher education. Thus, about a total of 8200 faculty members working in all the education faculties in the period when the scale was administered make up the population of the current study. The scale was delivered to all the teacher educators in the population by e-mail to be filled in the electronic environment.

In line with the first research problem, a scale was developed to measure teacher educators' perceptions of general subject matter competences on the basis of the opinions taken from four expert teacher educators, a literature review conducted and the opinions of 15 teacher educators from 3 different universities (Ankara, Gazi, Hacettepe universities).

In line with the second research question, the scale items were submitted to the review of seven experts and they gave their opinions about the suitability of items for being items of competences, their scope and content. Then the pilot study of the items was conducted by sending the draft scale to 212 teacher educators both in its pen and paper format and online format and then on the data collected from this pilot study, reliability analysis and exploratory factor analysis were conducted.

In line with the third and fourth research problems, the simple random sampling method was used to determine the sample and at the end of about a one-month period, a total of 789 faculty members were found to have filled in the online scale. This number was found to be sufficient with a $95 \%$ probability and $\pm 4 \%$ "tolerable error" ratio (Yazıcıoğlu \& Erdoğan, 2004). The demographic features of the faculty members having completed the scale are given below.

\subsection{Data Collection and Analysis}

In order to determine the extent to which teacher educators working in education faculties in Turkey perceive themselves as competent in training teachers, a scale developed by the researchers was used. First, the opinions of four experts in the field of teacher training having taken part in commissions established to determine teacher competences or having conducted research on teacher educators were sought to develop the scale. Then a literature review was conducted and the opinions of 15 teacher educators from three different universities (Ankara, Gazi, Hacettepe universities) were taken and as a result, the scale items were formed to measure teacher educators' perceptions of subject matter competences. Then, the scale items designed in the form of a five-point Likert scale were submitted to the review of a total of seven teacher educators to decide which items should be kept in the scale. In order to determine the construct validity of the scale, the scale was first administered to 212 teacher educators and Kaiser-Meyer-Olkin (KMO) test was conducted to determine the suitability of the data set obtained from these teacher educators for factor analysis. The Kaiser-Meyer-Olkin value was found to be .891 and Barlett test value was found to be $p=.000$. Thus, it was concluded that the data set is suitable for factor analysis.

As a result of the factor analysis, the scale was found to have a uni-dimensional structure. According to the results of the analysis conducted on the whole scale items, the factor loadings were found to be varying between 0.795 and 
0.363. The Cronbach Alpha reliability coefficient of the scale was found to be 0.986 ; thus, it was concluded that the scale is reliable.

The scale whose final form was given after the validity and reliability studies consists of 106 items designed in the form of a five-point Likert scale (Highly Competent, Competent, Partially Competent/Partially Incompetent, Need to be Developed, Highly Need to be Developed) was administered to 789 teacher educators and thus data were collected.

The data collection process followed is summarized in Table 1 .

Table 1. Characteristics of the data collected in the study

\begin{tabular}{|c|c|c|c|c|c|}
\hline Sub-purpose & Sort of Data & $\begin{array}{c}\text { Source of } \\
\text { Data }\end{array}$ & Type of Data & $\mathrm{n}$ & Data Analysis \\
\hline $\begin{array}{l}1^{\text {st }} \\
\text { sub-purpose }\end{array}$ & $\begin{array}{l}\text { Teacher educators' general subject matter } \\
\text { competences }\end{array}$ & $\begin{array}{c}\text { Teacher } \\
\text { Educators }\end{array}$ & $\begin{array}{l}\text { Qualitative } \\
\text { data }\end{array}$ & $4-15$ & $\begin{array}{c}\text { Descriptive analysis, } \\
\text { content validity }\end{array}$ \\
\hline $\begin{array}{c}2^{\text {nd }} \\
\text { sub-purpose }\end{array}$ & $\begin{array}{c}\text { Teacher educators' general subject matter } \\
\text { competences }\end{array}$ & $\begin{array}{c}\text { Teacher } \\
\text { Educators }\end{array}$ & $\begin{array}{c}\text { Quantitative } \\
\text { data }\end{array}$ & $7-212$ & $\begin{array}{l}\text { Content validity, } \\
\text { exploratory factor analysis }\end{array}$ \\
\hline $\begin{array}{l}3^{\text {rd }} \\
\text { sub-purpose }\end{array}$ & $\begin{array}{l}\text { Teacher educators' perceptions of general subject } \\
\text { matter competences }\end{array}$ & $\begin{array}{c}\text { Teacher } \\
\text { Educators }\end{array}$ & $\begin{array}{l}\text { Quantitative } \\
\text { data }\end{array}$ & 789 & $\begin{array}{l}\text { Percentage, frequency, } \\
\text { Kolmogrov Smirnov, } \\
\text { Median }\end{array}$ \\
\hline $\begin{array}{l}4^{\text {th }} \\
\text { sub-purpose }\end{array}$ & $\begin{array}{c}\text { Whether teacher educators' perceptions of general } \\
\text { subject matter competences vary significantly } \\
\text { depending on variables }\end{array}$ & $\begin{array}{c}\text { Teacher } \\
\text { Educators }\end{array}$ & $\begin{array}{l}\text { Quantitative } \\
\text { data }\end{array}$ & 789 & $\begin{array}{c}\text { Kolmogrov Smirnov, Mann } \\
\text { Whitney U, Kruskall Wallis } \\
\text { H }\end{array}$ \\
\hline
\end{tabular}

In addition, for the interpretation of the findings obtained as a result of the analysis of the data obtained from the scale of teacher educators' perceptions of general subject matter competences, the interval coefficient of $4 / 5=0.80$ was determined and thus the intervals were set. The intervals taken into consideration in the evaluations are shown in Table 2 (Büyüköztürk et al., 2011).

Table 2. Evaluation criteria of the scale of teacher educators' perceptions of general subject matter competences

\begin{tabular}{cccc}
\hline Response Options & Score & Score Interval & Scale Evaluation \\
\hline Highly need to be developed & 1 & $1.00-1.80$ & Very low perception of competence \\
Need to be developed & 2 & $1.81-2.60$ & Low perception of competence \\
Partially competent/partially incompetent & 3 & $2.61-3.40$ & Medium perception of competence \\
Competent & 4 & $3.41-4.20$ & High perception of competence \\
Highly competent & 5 & $4.21-5.00$ & Very high perception of competence \\
\hline
\end{tabular}

\section{Findings and Interpretations}

\subsection{Findings Related to the Teacher Educators' Perceptions of General Subject Matter Competences}

With the administration of the "Scale of teacher educators' perceptions of subject matter competences" to 789 teacher educators working in education faculties, it was attempted to determine how they perceive their own competences. The obtained findings are shown in Table 3.

Table 3. Teacher educators' perceptions of general subject matter competences $(n=789)$

\begin{tabular}{cccc}
\hline \multirow{2}{*}{ Competence Items } & \multicolumn{2}{c}{ Kolmogorov Smirnov test } & \multirow{2}{*}{ Median } \\
\cline { 2 - 3 } & $\mathrm{K}-\mathrm{S}$ & $\mathrm{p}$ & \\
\hline ALL THE ITEMS GENERAL (106 ITEMS) & 0.070 & $0.000^{*}$ & 4.11 \\
\hline
\end{tabular}

$* \mathrm{p}<0.05$ significant.

As can be seen in Table 3, the normality of the distribution of the whole scale was tested with Kolmogorov Smirnov test (Taşpınar, 2017) and it was found that the distribution is normal (K-S=0,070; $\mathrm{p}<0.05)$. Therefore, interpretations were made on the basis of the median values for the level of perception of each item. Thus, it was 
determined that the teacher educators' perceptions of general subject matter competences are high $(\mathrm{M}=4.11)$. Even in the competences with the lowest median values, the teacher educators found themselves competent at the medium level. When the items are evaluated in general, the remarkable findings can be summarized as follows.

The items in which the teacher educators' perceptions of general subject matter competences were found to be at the highest level $(\mathrm{M}=5.00)$ are; "Being sensitive to people, society and environment" "Establishing empathy" "Having the determination for self-development", "Being able to adapt to change to the degree which allows contribution to self-development", "Having self-confidence" "Caring about values education". It can be said that the teacher educators find themselves more competent in the items covering affective and personal characteristics.

The only item in which the teacher educators' perceptions of general subject matter competences are the lowest; that is, in which they see themselves partially competent/partially incompetent is "Establishing effective communication in a foreign language" $(\mathrm{M}=3)$. Thus, the area in which the teacher educators feel themselves the least competent is foreign language.

When the content of the uni-dimensional scale of competences developed in the current study is examined, on the basis of the qualitative evaluation of three experts, the items in the scale are grouped under the following sub-headings: scientific research, interdisciplinary research, specialized subject area knowledge, general culture knowledge, educational technologies, learning-teaching process, guidance, measurement and evaluation, personal features and values, professional development, foreign language, teacher training). As this grouping was qualitatively performed, no classification was performed on the basis of the quantitative data. Thus, below are given the findings and interpretations in relation to these sub-headings.

\subsubsection{Scientific Research}

The teacher educators' perceptions of the items related to scientific research in the scale of general subject matter competences were found to be $\mathrm{M}=4$ for all the related items. In this regard, when the median values obtained by the teacher educators for the following items: "using multiple perspectives in their research on teacher training", "conducting research by using different methods to improve the learning-teaching process", "conducting research on the issue of developing teaching methods, techniques and strategies" are taken into consideration, it can be said that they feel competent in terms of conducting scientific research.

\subsubsection{Interdisciplinary Research}

The teacher educators' perceptions of the competence items related to establishing connections with different disciplines such as "relating the discipline-specific knowledge to the knowledge in different disciplines", "cooperating with colleagues from their own discipline or from other disciplines", "conducting academic works together with academicians from different disciplines", "continuously following interdisciplinary developments related to their own discipline" are high $(\mathrm{M}=5.00)$. Thus, it can be said that the teacher educators feel highly competent in terms of conducting inter-disciplinary research and cooperating for information transfer

\subsubsection{Specialized Subject Area Knowledge}

While the teacher educators feel highly competent in the items related to knowledge and skill dimensions such as "having knowledge and skills about the concepts", "principles and theories related to their own subject area", "analyzing the problems concerning the teaching of subject area", "producing new ideas about the teaching of their own subject area", "reflecting theories of their own subject area into their practice", they also perceive themselves highly competent in the item having emotional aspects "being aware of the values of their own subject area" $(\mathrm{M}=5.00)$.

\subsubsection{General Culture Knowledge}

The teacher educators feel highly competent in the items related to knowledge required for their subject area such as "having philosophical knowledge about their own subject area", "having science history knowledge about their own subject area", "having social sciences knowledge necessary for their own subject area", "having technological knowledge necessary for their own subject area", "having critical pedagogy knowledge" $(M=4.00)$. In this regard, it can be said that the teacher educators see themselves competent in relation to knowledge of basic sciences required for the effective teaching of their subject area.

\subsubsection{Educational Technologies}

The teacher educators feel highly competent in the items related to educational technologies such as "using technology-assisted (smart boards, web 2.0, software programs) learning environments to meet different needs of pre-service teachers", "making use of information and communication technologies to share information", "evaluating resources in technological environments (data bases, online sources etc.) in terms of accuracy and 
suitability", "supporting participating in distance learning environments" $(\mathrm{M}=5.00)$. The teacher educators see themselves competent in "using technology-assisted learning environments" and "using technology to share information" $(\mathrm{M}=4.00)$.

\subsubsection{Learning-Teaching Process}

The teacher educators feel highly competent in the items related to the learning-teaching process such as "developing instructional designs", "preparing program designs" $(\mathrm{M}=5.00)$. In addition, they see themselves competent in participating in relevant program evaluation studies though not as competent as in preparing programs. This might be because the teacher educators view program evaluation as an activity requiring more competence.

The teacher educators see themselves highly competent in "developing instructional designs to support teaching in their subject area", "developing instructional and program designs" and "organizing activities in line with the course objectives". They also see themselves competent in terms of "contributing to the works done to develop program and instructional designs" and "evaluating programs related to their own subject area".

The teacher educators also feel highly competent in "planning, implementing and evaluating instructional methods and techniques" $(\mathrm{M}=5.00)$. In addition, they see themselves competent in "designing creative learning environments in their own subject area", "using different feedback strategies in compliance with course objectives", and "contributing to pre-service teachers' higher order thinking skills".

Another important element in the learning-teaching process is classroom management. The teacher educators see themselves highly competent in terms of "having classroom management skills".

\subsubsection{Guidance}

The teacher educators see themselves highly competent in "providing pre-service teachers with opportunities to express themselves", "interacting with pre-service teachers with different levels of development and learning", "creating environments for pre-service teachers to recognize their strengths and weaknesses and develop their weak sides", "adjusting learning strategies in a suitable manner" $(M=5.00)$. Parallel to these perceptions, the teacher educators also perceive themselves competent in "providing learning opportunities for pre-service teachers having special needs in compliance with course objectives" $(\mathrm{M}=4.00)$.

\subsubsection{Measurement and Evaluation}

The teacher educators perceive themselves highly competent in "preparing different types of exam questions in line with course objectives" and "scoring student responses in objectives ways" $(\mathrm{M}=5.00)$. On the other hand, they see themselves competent in "applying the measurement complying with course objectives" and "analyzing the results of the exam in such a way as to support the accomplishment of course objectives" (M=4.00).

The teacher educators also feel highly competent in "analyzing the effects of program, instruction and materials", "developing strategies to increase the efficiency in teaching on the basis of the results obtained from the evaluation of the instruction" and "periodically revising the process of measurement and evaluation to improve the quality of instruction" ( $\mathrm{M}=4.00)$.

\subsubsection{Personal Characteristics and Values}

The teacher educators perceive themselves highly competent in the items related to personality characteristics and values such as "struggling against injustice", "protecting others' rights", "having the determination for self-development", "using communication skills", "establishing empathy", "being sensitive towards people, society and environment", "adapting to change enough to contribute to self-development" and "having self-confidence" $(\mathrm{M}=5.00)$. The teacher educators see themselves competent in "applying leadership processes that can improve their personal leadership characteristics" $(\mathrm{M}=4.00)$.

The teacher educators perceive themselves highly competent in relation to tasks related to interpersonal relationships and communication skills such as "being a role model", "managing individual differences" and "developing democratic ideals", "exhibiting knowledge and skills that can be role model to pre-service teachers", and "acting in compliance with the rules of ethics" $(\mathrm{M}=5.00)$. Similarly, they see themselves highly competent in "guiding pre-service teachers in terms of complying with the rules of ethics".

\subsubsection{Professional Development}

The teacher educators see themselves highly competent in "monitoring the reflections of social development in relation to their profession development on school and education". At the same time, they feel competent in terms of "being a role model to pre-service teachers by following contemporary scientific advancements in the 
learning-teaching process" $(\mathrm{M}=4.00)$.

\subsubsection{Foreign Language}

The teacher educators find themselves partially competent in "establishing effective oral communication in a foreign language" $(\mathrm{M}=3.00)$. The lowest perception of competence was found for this item. They feel more competent in "establishing written communication" when compared to oral communication ( $\mathrm{M}=4.00)$.

\subsubsection{Teacher Training}

The teacher educators stated that they are competent in items related to the task of teacher training such as "perceiving themselves as a good teacher", "developing suggestions for improving teacher training" and" integrating up-to-date scientific developments in their area of specialty into teacher training programs" $(\mathrm{M}=4,00)$. They perceive themselves highly competent in "having a good vision of teacher training" $(M=5.00)$.

The teacher educators see themselves highly competent in "valuing the ideas and products of pre-service teachers" $(\mathrm{M}=5.00)$. In addition, they see themselves competent in "using learning strategies in their own subject area" and "imparting them to pre-service teachers", "helping them relate their prior knowledge to the organization of their new knowledge regarding the subject area" and "enabling them to develop their critical thinking skills related to the subject area" and "providing guidance for them to develop their problem solving skills" $(M=4.00)$.

The teacher educators perceive themselves highly competent in "explaining the national and international problems of teacher training with an analytic and holistic viewpoint and "developing solution suggestions for the establishment of conditions necessary for training qualified teachers" ( $M=5.00)$. In addition, they feel competent in "organizing their instruction in such a way as to be a role model to pre-service teachers so that they can find a balance between theoretical knowledge and practice" $(\mathrm{M}=4.00)$.

The teacher educators see themselves high competent in "teaching pre-service teachers how to impart course objectives to students". Moreover, they see themselves competent in "teaching pre-service teachers how to impart cognitive, affective and psycho-motor objectives to students" ( $\mathrm{M}=4.00)$.

3.2 Findings Related to Whether the Teacher Educators' Perceptions of General Subject Matter Competences Vary Significantly Depending on Some Variables

Analyses were conducted to determine whether the teacher educators' competence perceptions vary significantly depending on gender, discipline, type of the university where they are working, whether they have teaching experience as a teacher, type of the faculty they graduated from, academic title and professional seniority. Results obtained from these analyses are presented in Table 4. 
Table 4. Teacher educators' competence perceptions in relation to some variables

\begin{tabular}{|c|c|c|c|c|c|c|c|}
\hline \multirow[t]{2}{*}{ Variables } & \multirow[t]{2}{*}{$\mathrm{N}$} & \multicolumn{2}{|c|}{ Kolmogorov Smirnov Test } & \multirow[t]{2}{*}{ Median } & \multirow[t]{2}{*}{ Mean Rank } & \multicolumn{2}{|c|}{$\begin{array}{c}\text { Mann Whitney } \\
\text { U test }\end{array}$} \\
\hline & & $\mathrm{K}-\mathrm{S}$ & $\mathrm{p}$ & & & $\mathrm{U}$ & $\mathrm{p}$ \\
\hline \multicolumn{8}{|l|}{ Gender } \\
\hline Female & 367 & 0.071 & $0.000^{*}$ & 4.10 & 397.93 & \multirow{2}{*}{76361.50} & \multirow{2}{*}{0.736} \\
\hline Male & 422 & 0.070 & $0.000 *$ & 4.13 & 392.45 & & \\
\hline \multicolumn{8}{|l|}{ Discipline } \\
\hline Educational Sciences & 324 & 0.068 & $0.001 *$ & 4.16 & 399.04 & \multirow{2}{*}{74021.00} & \multirow{2}{*}{0.678} \\
\hline Subject Area & 465 & 0.075 & $0.000^{*}$ & 4.09 & 392.18 & & \\
\hline \multicolumn{8}{|l|}{ Type of University } \\
\hline State & 744 & 0.069 & $0,000^{*}$ & 4,11 & 394,29 & \multirow{2}{*}{16212.00} & \multirow{2}{*}{0.722} \\
\hline Foundation & 45 & 0.151 & $0.012 *$ & 4.15 & 406.73 & & \\
\hline \multicolumn{8}{|l|}{ Experience as a Teacher } \\
\hline Yes & 482 & 0.067 & $0.000 *$ & 4.08 & 384.09 & \multirow{2}{*}{68728.00} & \multirow{2}{*}{0.092} \\
\hline No & 307 & 0.088 & $0.000^{*}$ & 4.21 & 412.13 & & \\
\hline \multicolumn{8}{|l|}{ Type of Faculty Graduated } \\
\hline Teacher Training Faculties & 629 & 0.070 & $0.000^{*}$ & 4.10 & 391.26 & \multirow{2}{*}{47970.00} & \multirow[b]{2}{*}{0.361} \\
\hline Other Faculties & 160 & 0.072 & $0.043 *$ & 4.16 & 409.69 & & \\
\hline \multicolumn{8}{|l|}{ Academic Title } \\
\hline Prof.Dr. & 103 & 0.102 & $0.010^{*}$ & 4.11 & 384.10 & \multirow{6}{*}{2.944} & \multirow{6}{*}{0.709} \\
\hline Assoc. Prof. & 158 & 0.080 & $0.016^{*}$ & 4.10 & 409.60 & & \\
\hline Ass. Prof. & 276 & 0.079 & $0.000^{*}$ & 4.07 & 380.19 & & \\
\hline Lecturer Dr. and Lecturer & 58 & 0.071 & 0.200 & 4.13 & 402.69 & & \\
\hline Research Ass. Dr. and Research Ass. & 187 & 0.076 & $0.011^{*}$ & 4.17 & 406.14 & & \\
\hline Other Lecturers & 7 & 0.294 & 0.068 & 3.99 & 448.29 & & \\
\hline \multicolumn{8}{|l|}{ Academic Status } \\
\hline Ass. Prof., Assoc. Prof., Prof. & 537 & 0.078 & $0.000^{*}$ & 4.28 & 444.81 & \multirow{2}{*}{40916.00} & \multirow{2}{*}{$0.000^{*}$} \\
\hline Others & 252 & 0.072 & $0.003 *$ & 3.87 & 288.87 & & \\
\hline \multicolumn{8}{|l|}{ Seniority } \\
\hline $1-10$ years & 298 & 0.057 & $0.017 *$ & 3.94 & 305.03 & \multirow{3}{*}{78.136} & \multirow{3}{*}{$0.000^{*}$} \\
\hline $11-20$ years & 240 & 0.077 & $0.002 *$ & 4.17 & 429.91 & & \\
\hline 21 years and more & 251 & 0.107 & $0.000 *$ & 4.41 & 468.43 & & \\
\hline
\end{tabular}

$* \mathrm{p}<0.05$.

As can be seen in Table 4, the normality of distribution in relation to all the variables was tested with Kolmogorov Smirnov test and the distribution was found to be not normal. Therefore, Mann Whitney U test was used for comparisons.

In order to determine whether the teacher educators' perceptions vary significantly depending on gender, discipline (educational sciences/subject area education), type of the university where they are working, whether they have any experience of teaching as a teacher and type of the faculty graduated (teacher training faculties and other faculties), Mann Whitney U test was run. . The result of the analysis showed that the teacher educators' competence perceptions do not vary significantly depending on these variables $(\mathrm{U}=76361.50 ; \mathrm{U}=74021.00$; $\mathrm{U}=16212.00 ; \mathrm{U}=68728.00 ; \mathrm{U}=47970.00 ; \mathrm{p}<0.05$ ). It can be concluded that gender, discipline, type of the university where they are working, whether they have experience of teaching as a teacher and type of the faculty graduated are not variables influential on the teacher educators' competence perceptions.

In order to determine whether the teacher educators' perceptions vary significantly depending on academic title, Kruskall Wallis $\mathrm{H}$ test was run. The result of the analysis showed that the teacher educators' competence perceptions do not vary significantly depending on their academic title $(U=2.944 ; p<0.05)$. Thus, it can be argued that academic title is not a variable influential on the teacher educators' competence perceptions.

Moreover, another classification on the basis of the titles of the teacher educators was made in the current study: a) Ass. Prof, Assoc. Prof., Prof and b) other lecturers and it was investigated whether there is a significant difference 
between the competence perceptions of these two groups of academicians and a significant difference was found in favor of the academicians in the group a (Ass. Prof., Assoc. Prof and Prof) who are more experienced.

In order to determine whether the teacher educators' competence perceptions vary significantly depending on professional seniority, Kruskall Wallis $\mathrm{H}$ test was run. The results revealed that the teacher educators' competence perceptions vary significantly depending on professional seniority $\left(\mathrm{K}-\mathrm{W}-\mathrm{H}_{(2)}=78.136 ; \mathrm{p}<0.05\right)$. In order to determine the source of this difference, Whitney $U$ test was conducted and significant differences were found between the three levels of professional seniority. When the mean ranks and medians were examined, the group seeing themselves the most competent was found to be comprised of teacher educators having 21 years and more professional experience. Thus, it can be argued that with increasing professional seniority, the teacher educators tend to see themselves more competent.

\section{Results and Discussion}

The results related to teacher educators' perceptions of general subject matter competences and whether their competence perceptions vary significantly depending on some variables are given below:

- The teacher educators see themselves highly competent in general subject matter competences. Even in the area in which they feel the least competent, they see themselves partially competent. Similarly, in a study conducted by Czerniawski et al. (2015) in Belgium, Holland and Israel, it was found that the teacher educators see themselves highly competent.

- The fact that the teacher educators see themselves highly competent in all the subject matter competences can also be associated with "Dunning-Kruger effect". In other words, they may tend to see themselves better than what they really are and to have misconceptions about themselves (Kruger \& Dunning, 1999). The reason for the difference between the questionnaire and observation findings is thought to be that the teachers did not respond to the questionnaire items correctly due to some concerns. This might hold true for the current study.

- The teacher educators especially see themselves highly competent in the items regarding personal characteristics and values. In a study conducted by Grobgeld et al. (2016) in Israel with the participation of 178 teacher educators to determine the profile of these teacher educators, it was found that the teacher educators see themselves competent in terms of personal characteristics and values and care more about their identity of a teacher than their identity of a researcher or a member of an organization.

- One of the most important competence areas for teacher educators according to Bourgonje and Tromp (2011) is the competence of foreign language. In the current study, the competence items in which the teacher educators perceive themselves as the least competent are in the competence area of foreign language. In a study conducted by Küçüksüleymanoğlu (2007), the faculty members' competence of foreign language was also found to be low.

- The teacher educators were found to feel highly competent in the items related to science and academic ethics. However, Köklü (2003) and Özder et al. (2014) found that teacher educators exhibited behaviors not complying with science ethics on the basis of their responses to the questions asked about themselves and their colleagues. The existing research indicates that this difference is because teacher educators tend to state the unethical behaviors they have observed in their colleagues rather than their own.

- The teacher educators think that they are good role models to pre-service teachers. This finding is also supported by the study by Timmerman (2009) and Fourie and Fourie (2015). It can be said that the teacher educators think that they are good role models as they teach at the higher education level.

- The teacher educators were found to see themselves highly competent in items related to technology. It can be said that the teacher educators see themselves more competent in using technology to share information rather than using it in technology-assisted learning environments. In their study, Özüdoğru and Çakır (2014) reached a similar conclusion. However, Kavrat and Türel (2013) found that faculty members cannot use technology effectively. Similarly, in a study conducted by Krumsvik (2014) in Norway, the digital competences of the teacher educators in Norway were found to be at the basic level. This difference may be because of the different samples used in different studies.

- The teacher educators see themselves highly competent in the items related to scientific research. Similarly, in their study conducted in Belgium, Holland and Israel, Czerniawski et al. (2015) found that the teacher educators see themselves highly competent. Cao et al. (2019) conducted a study on 115 teacher educators in two universities in China and they found that the majority of the teacher educators also see themselves as researchers. However, as stated by Çetinsaya (2014), though the increase seen in the publication performance in Turkey, a decrease was experienced in the number of citations accepted to be an indicator of the quality of 
publications and also the increase seen in the number of publications not cited indicate that the quality of the publications is not at the desired level.

- While the teacher educators perceive themselves as highly competent in relation to the processes covering measurement and evaluation, they see themselves competent in terms of the monitoring processes concerning the continuity of the process. Parallel to these findings, Goubeaud and Yan (2004) found that the teacher educators conduct performance-based evaluations for the sake of the continuity of the process. Zeichner et al. (2015) found that faculty members' being in effective communication and cooperation increased their job satisfaction and at the same time, their tendency to take more responsibility. In the current study, the teacher educators' perception of their competence to work in cooperation with their colleagues was also found to be high.

- While the teacher educators feel highly competent in learning to learn, they feel less competent in imparting this skill to pre-service teachers. In their study conducted on the teacher educators in Israel and Holland, Tillemma and Kremer- Hayon (2002) found that the teacher educators have difficulty in using self-regulated learning, which contradicts with the finding of the current study; yet, their having difficulty in transmitting this skill to pre-service teachers supports the finding of the current study. Donche and Van Petegem (2011) determined that the teacher educators have different concepts in relation to learning to teach and that these concepts are moderately associated with teaching strategies.

- The teacher educators stated that they are highly satisfied with the task of training teachers. Van Velzen et al. (2010) found that although the teacher educators find it difficult in their first years, they feel happy and proud about training teachers.

- The teacher educators see themselves highly competent in the items related to subject matter competences. Parallel to this finding, Tryggvason (2012) also reported that the teacher educators see themselves strong in terms of instructional qualifications.

- The teacher educators' perceptions of competence in planning, implementing and evaluating instructional methods and technologies in compliance with course objectives in their subject area are high. This finding is parallel to the finding reported by McAllister and Irvine (2000). Contrary to this finding, Arslantaş (2011) reported that nearly $60 \%$ of the pre-service teachers think that teacher educators are not competent enough in using teaching strategies, methods and techniques. Tryggvason (2009) noted that the reason behind the success of Finnish inquiry-based teaching is that Finnish teacher educators provide guidance for pre-service teachers to find their own teaching styles and that they find themselves competent in using different instructional methods and techniques.

- The teacher educators see themselves competent in relation to their own professional development. Similarly, in their study conducted on 562 teacher educators in Belgium, Israel and Holland to determine their professional learning and development needs, Czerniawski et al. (2015) found that that according to the teacher educators, current developments in teacher training, good applications, program development, research skills, technology and social media are areas to be mastered for professional development. And the teacher educators see themselves highly competent in these areas.

- As stated by Tillema and Kremer-Hayon (2005), there is a search for solutions to problem such as not being able to reflect theory in practice and not having the reactions expected, while providing guidance to pre-service teachers. In the current study, the teacher educators perceive themselves as competent in applying theory into practice and providing creative learning environments for pre-service teachers to find solutions to problems. Contrary to this finding, in the study by Tekmen and Kalelioğlu (2014), the participating pre-service teachers mentioned weaknesses in their departments, deficiencies in the lesson plans of their instructors, lack of experience of their instructors and lack of practice opportunities.

- The teacher educators see themselves competent in making efforts to develop life-long learning skills in pre-service teachers. This finding is parallel to the findings reported by Konokman and Yelken (2014). As stated by Van Velzen et al. (2010), for teacher educators to be life-long learning individuals, courses are organized by Mofet Institute in Israel and their professional development is supported in different ways.

- As stated by Lunenberg and Korthagen (2003), while teacher educators are serving as advisors and delivering their classes at undergraduate and graduate levels, they need to have the competences of qualified teacher educators and to be qualified enough to teach teaching competences to their students. In this regard, the teacher educators see themselves competent.

The results obtained about whether the teacher educators' competence perceptions vary significantly depending on 
gender, discipline, type of the university where they are working, type of the faculty graduated, academic title and professional seniority are given below:

- The teacher educators' competence perceptions were found to be not varying by gender and type of the university where they are working (state/foundation); both groups see themselves competent. This finding is parallel to the findings reported by Tümkaya and Hurioğlu (2013) and Uysal (2013). However, in the study conducted by Ghosh and Guha (2016) on 221 teacher educators in India, it was found that the female teacher educators are more motivated to do their job. This might be because of the samples from different geographies.

- The teacher educators' competence perceptions were found to be not varying significantly depending on discipline (educational sciences/subject area); both groups see themselves competent. Murat et al. (2006) found that the pre-service teachers' competence perceptions of their teacher educators vary significantly depending on their grade level but not on their department.

- The teacher educators' competence perceptions were found to be not varying significantly depending whether having experience of teaching as a teacher. Thus, it seems that having experience of teaching as a teacher is not influential on teacher educators competence perceptions; yet, Van Velzen et al. (2010) conducted semi-structured interviews with 11 novice teacher educators from six different countries and stated that teaching experience or doctoral degree is a pre-requisite for being a teacher educator. Moreover, according to Zeichner et al. (2015), for effective teacher training, cooperation of society, school and teacher training programs is needed and, in this regard,, pre-service teachers need to gain more experience at school.

- The teacher educators' competence perceptions were found to be not varying significantly depending on the faculty graduated (teacher training faculties and other faculties). This can be because; as stated by Tryggvason (2012), subject area educators and other teacher educators are in a close interaction with each other and this contributes to the formation of a collective identity of self-confidence and thus they become powerful in terms of instructional qualifications.

- The teacher educators' competence perceptions were found to be not varying depending on academic title. This finding is supported by Uysal (2003). But, in another classification of the teacher educators made in the current study, the more experienced teacher educators were found to perceive themselves as significantly more competent.

- The teacher educators' competence perceptions were found to be varying significantly depending on professional seniority. The competence perception of the teacher educators having 11-20 years of professional experience was found to be higher than that of the teacher educators having 1-10 years of professional experience. Tümkaya and Hurioğlu (2013) also found that with increasing number of years in the profession, the academicians' teaching responsibility, tendency to be more scientific and to conduct research also increased. This can be as stated by Izadinia (2014) because the teacher educators with less professional experience generally have negative opinions about their abilities and professional identity.

\section{Suggestions}

Given that the teacher educators feel relatively less competent in the areas of foreign language, using technology in education, scientific research and measurement and evaluation, priority can be given to develop related competences in faculty members working in education faculties to improve the learning-teaching process. Teacher educators can be provided with more opportunities to improve their command of foreign language abroad. In the performance evaluation of teacher educators, more emphasis can be put on these competence areas. In this regard, teacher educators can be encouraged to conduct self-evaluation in these competence areas. In addition, teachers/teacher educator candidates can be objectively evaluated by their colleagues. Professional development needs of each teacher educator can be determined. Research can be conducted on the competences of teacher educators on the basis of concrete indicators such as observation results and analysis of their works.

In a larger sample, explanatory and confirmatory factor analyses of the scale can be conducted. In this way, both the reliability of the scale can be tested and its dimensions can be determined through numerical analyses.

\section{References}

Andrew, L. (2007). Comparison of teacher educators' instructional methods with the constructivist ideal. The Teacher Educator, 42(3), 157-184. https://doi.org/10.1080/08878730709555401

Arslantaş, H. (2014). Student views regarding teaching staffs' sufficiencys in teaching strategies-methods and techniques, communication. Mustafa Kemal Üniversitesi Sosyal Bilimler Enstitüsü Dergisi, 8(15), 487-506. 
Aslan, C. (2010). Türkçe eğitimi programlarında lisansüstü öğrenim gören öğrencilerin akademik özyeterliklerine ilişkin görüşleri. Mehmet Akif Ersoy Üniversitesi Ĕ̆itim Fakültesi Dergisi, 10(19), 87-115.

Association of Teacher Educators. (2003). Retrieved from http://www.ate1.org/pubs/Standards.cfm

Bourgonje, P., \& Tromp, R. (2011). Quality educators: An international study of teacher competences and standards. Oxfam Novib.

Büyüköztürk, Ş., Çokluk, Ö., \& Köklü, N. (2011). Sosyal bilimler için istatistik. Ankara: Pegem Akademi.

Caena, F. (2012). Education: Policy support for teacher educators. Retrieved from http://ec.europa.eu/education/events/2012/educator/caena_en.pdf

Cao, Y., Postareff, L., Lindblom-Ylänne, S., \& Toom, A. (2019). Teacher educators' approaches to teaching and connections with their perceptions of the closeness of their research and teaching. Teaching and Teacher Education, 85, 125-136. https://doi.org/10.1016/j.tate.2019.06.013

Çetinsaya, G. (2014). Büyüme, kalite, uluslararasılaşma: Türkiye yükseköğretimi için bir yol haritası. Ankara: Yükseköğretim Kurulu.

Czerniawski, G., MacPhail, A., \& Guberman, A. (2015). Teacher educators' professional learning and development needs. British Educational Research Association (BERA) Konferansında sunulmuş bildiri, Queen's University, Belfast, Northern Ireland.

Donche, V., \& Van Petegem, P. (2011). Teacher educators' conceptions of learning to teach and related teaching strategies. Research Papers in Education, 26(2), 207-222. https://doi.org/10.1080/02671522.2011.561979

Drent, M., \& Meelissen, M. (2008). Which factors obstruct or stimulate teacher educators to use ICT innovatively? Computers \& Education, 51(1), 187-199. https://doi.org/10.1016/j.compedu.2007.05.001

Fisher, B., Short, B., McBee, R., \& Venditti, K. (2008). The Teacher Educator Standards From the Association of Teacher Educators, Winter Conference Standards Clinic, New Orleans, LA, February, 2008.

Fourie, E., \& Fourie, U. (2015). As educators of teachers, where and when do our responsibilities end? Journal of Social Sciences, 42(3), 247-257. https://doi.org/10.1080/09718923.2015.11893412

Gelişli, Y. (2009). The effect of student centered instructional approaches on student success. Procedia-Social and Behavioral Sciences, 1(1), 469-473. https://doi.org/10.1016/j.sbspro.2009.01.085

Ghosh, M., \& Guha, A. (2016). Organizational Climate of Teacher Education Institutions in West Bengal in relation to Teacher Educators' Motivation to work. IRA-International Journal of Education and Multidisciplinary Studies, 4, 135-146. https://doi.org/10.21013/jems.v4.n1.p15

Goodwin, A. L., Smith, L., Souto-Manning, S., Cheruvu, R., Tan, M. Y., Reed, R., \& Taveras, L. (2014). What should teacher educators know and be able to do? Perspectives from practicing teacher educators. Journal of Teacher Education, 65(4), 284-302. https://doi.org/10.1177/0022487114535266

Goubeaud, K., \& Yan, W. (2004). Teacher educators' teaching methods, assessments, and grading: A comparison of higher education faculty's instructional practices. The Teacher Educator, 40(1), 1-16. https://doi.org/10.1080/08878730409555348

Grobgeld, E., Teichman-Weinberg, A., Wasserman, E., \& Barchilon Ben-Av, M. (2016). Role perception among faculty members at teacher education colleges. Australian Journal of Teacher Education, 41(5), 78-98. https://doi.org/10.14221/ajte.2016v41n5.6

Holme, R., Robb, A., \& Berry, W. (2016). Becoming a teacher educator-the motivational factors. European Journal of Teacher Education, 39(3), 1-15. https://doi.org/10.1080/02619768.2016.1194391

Izadinia, M. (2014). Teacher educators' identity: A review of literature. European Journal of Teacher Education, 37(4), 426-441. https://doi.org/10.1080/02619768.2014.947025

Jusuf, H. (2005). Improving teacher quality, a keyword for improving education facing global challenges. Turkish Journal of Educational Technology, 4(1), 33-37.

Karasar, N. (2009). Bilimsel araştırma yöntemi. Ankara: Nobel.

Kavrat, B., \& Türel, Y. K. (2013). Çevrimiçi uzaktan eğitimde öğretmen rollerini ve yeterliliklerini belirleme ölçeği geliştirme. The Journal of Instructional Technologies \& Teacher Education, 1(3), 23-33.

Köklü, N. (2003). Akademisyenlerin araştırma etiği konusundaki görüşleri. Eğitim Bilimleri ve Uygulama, 2(4), 137-151. 
Konokman, G. Y., \& Yelken, T. Y. (2014). Eğitim fakültesi öğretim elemanlarının yaşam boyu öğrenme yeterliklerine ilişkin algıları. Hacettepe Üniversitesi Eğitim Fakültesi Dergisi, 29(29-2).

Koster, B., \& Dengerink, J. J. (2008). Professional standards for teacher educators: how to deal with complexity, ownership and function. Experiences from the Netherlands. European Journal of Teacher Education, 31(2), 135-149. https://doi.org/10.1080/02619760802000115

Kruger, J., \& Dunning, D. (1999). Unskilled and unaware of it: How difficulties in recognizing one's own incompetence lead to inflated self-assessments. Journal of Personality and Social Psychology, 77(6), 1121-1134. https://doi.org/10.1037/0022-3514.77.6.1121

Krumsvik, R. J. (2014). Teacher educators' digital competence. Scandinavian Journal of Educational Research, 58(3), 269-280. https://doi.org/10.1080/00313831.2012.726273

Küçüksüleymanoğlu, R. (2007). Eğitim fakültesi öğretim elemanlarının tükenmişlik düzeyleri. Eğitim Araştırmalarl, 28, 101-112.

Lunenberg, M., \& Korthagen, F. A. (2003). Teacher educators and student-directed learning. Teaching and Teacher Education, 19(1), 29-44. https://doi.org/10.1016/S0742-051X(02)00092-6

Martinez, K. (2008). Academic induction for teacher educators. Asia-Pacific Journal of Teacher Education, 36(1), 35-51. https://doi.org/10.1080/13598660701793376

McAllister, G., \& Irvine, J. J. (2000). Cross cultural competency and multicultural teacher education. Review of Educational Research, 70(1), 3-24. https://doi.org/10.3102/00346543070001003

Melief, K., Van Rijswijk, M., \& Tigchelaar, A. (2012). Accounting for the Dutch professional standard of teacher educators. Pedagógusképzés, 1(4), 118-180.

Millî Eğitim Bakanlığı [MEB]. (2008). Öğretmen yeterlikleri. Ankara: Milli Eğitim Bakanlığı.

MOFET Institute. (2016). Retrieved from http://www.mofet.macam.ac.il/eng/about/Pages/default.aspx

Murat, M., Aslantaş, H. İ., \& Özgan, H. (2006). Öğretim elemanlarının sınıf içi eğitim öğretim etkinlikleri açısından değerlendirilmesi. Gazi Üniversitesi Gazi Eğitim Fakültesi Dergisi, 26(3), 263-278.

Özder, H., Işıktaş, S., \& Erdoğan, F. (2014). Öğretim elemanlarının akademik etik kurallardan haberdar olma ve onaylama dereceleri. International Journal of New Trends in Arts, Sports \& Science Education (IJTASE), $3(1), 22-37$.

Özüdoğru, G., \& Çakır, H. (2014). Öğretim elemanlarının bilişim teknolojileri kullanımında öğretmen adaylarına model olma farkındalıklarının incelenmesi. Ahi Evran Üniversitesi Kırşsehir Eğitim Fakültesi Dergisi (KEFAD), 15(2), 207-226.

Swennen, A., Jones, K., \& Volman, M. (2010). Teacher educators: their identities, sub-identities and implications for professional development. Professional Development in Education, 36(1-2), 131-148. https://doi.org/10.1080/19415250903457893

Tanrıöğen, A. (2009). Bilimsel araştırma yöntemleri. Ankara: Anı.

Taşpınar, M. (2017). Sosyal bilimlerde SPSS uygulamalı nicel veri analizi. Ankara: Pegem Akademi Yayıncılık. https://doi.org/10.14527/9786052410585

Tekmen, B., \& Kalelioğlu, F. (2014). Öğretmen adaylarının aldıkları eğitimin kalitesi ile ilgili görüşleri. Ögretmen Yetiştirme Politikaları ve Sorunları Uluslararası Seтроzуити, 19-22.

Tillema, H. H., \& Kremer-Hayon, L. (2002). "Practising what we preach"-teacher educators' dilemmas in promoting self-regulated learning: A cross case comparison. Teaching and Teacher Education, 18(5), 593-607. https://doi.org/10.1016/S0742-051X(02)00018-5

Tillema, H., \& Kremer-Hayon, L. (2005). Facing dilemmas: Teacher-educators' ways of constructing a pedagogy of teacher education. Teaching in Higher Education, 10(2), 203-217. https://doi.org/10.1080/1356251042000337954

Timmerman, G. (2009). Teacher educators modelling their teachers? European Journal of Teacher Education, 32(3), 225-238. https://doi.org/10.1080/02619760902756020

Tryggvason, M. T. (2009). Why is Finnish teacher education successful? Some goals Finnish teacher educators have for their teaching. European Journal of Teacher Education, 32(4), 369-382. https://doi.org/10.1080/02619760902756020 
Tümkaya, S., \& Hurioğlu, A. G. L. (2013). Öğretim elemanlarının yansıtıcı düşünme eğilimleri. Çukurova Üniversitesi Sosyal Bilimler Enstitüsü Dergisi, 22(1), 243-256.

Uysal, İ. (2013). Akademisyenlerin genel öz-yeterlik inançları: AİBÜ eğitim fakültesi örneği. Trakya Üniversitesi Eğitim Fakültesi Dergisi, 3(2), 144-151.

Van Velzen, C., Van der Klink, M., Swennen, A., \& Yaffe, E. (2010). The induction and needs of beginning teacher educators. Professional Development in Education, 36(1-2), 61-75. https://doi.org/10.1080/19415250903454817

Williams, J. (2014). Teacher educator professional learning in the third space implications for identity and practice. Journal of Teacher Education, 65(4), 315-326. https://doi.org/10.1177/0022487114533128

Yazıcıoğlu, Y., \& Erdoğan, S. (2004). Spss uygulamalı bilimsel araştırma yöntemleri. Ankara: Detay.

Zeichner, K., Payne, K. A., \& Brayko, K. (2015). Democratizing teacher education. Journal of Teacher Education, 66(2), 122-135. https://doi.org/10.1177/0022487114560908

\section{Note}

Note 1. This paper has been prepared from the author's $\mathrm{PhD}$ thesis.

\section{Copyrights}

Copyright for this article is retained by the author(s), with first publication rights granted to the journal.

This is an open-access article distributed under the terms and conditions of the Creative Commons Attribution license (http://creativecommons.org/licenses/by/4.0/). 